\title{
Methodology for the design of a multilayer polymeric membrane system with potential use in hemofiltration
}

\section{Metodología para el diseño de un sistema de membranas poliméricas multicapa con uso potencial en hemofiltración}

\author{
NUÑEZ-HERNÁNDEZ Lourdes Nohemi ${ }^{1}{ }^{\dagger} *$ KANTUN-UICAB María Cristina ${ }^{2}$, PÉREZ- \\ CASTAÑEDA Laura Maryela ${ }^{3}$, and TÉLLEZ-MARTÍNEZ Jorge Sergio ${ }^{1}$
}

${ }^{1}$ Universidad Politécnica de Juventino Rosas. Academia de Ingeniería en Metalúrgica. Hidalgo 102, Comunidad de Valencia, Santa Cruz de Juventino Rosas, Gto.; México.

${ }^{2}$ Universidad Politécnica de Juventino Rosas. Academia de Ingeniería en Plásticos. Hidalgo 102, Comunidad de Valencia, Santa Cruz de Juventino Rosas, Gto.; México.

${ }^{3}$ Universidad Tecnológica de Tamaulipas Norte. Academia de Procesos y Operaciones Industriales. Av U. Tecnològica No. 1555, C. P. 88770, Reynosa, Tamaulipas; México.

\author{
ID $1^{\text {st }}$ Author: Lourdes Nohemi Nuñez-Hernández / ORC ID: 0000-0002-3684-7700, CVU CONACYT ID: 1017764 \\ ID $1{ }^{\text {st }}$ Coauthor: María Cristina Kantun-Uicab / ORC ID: 0000-0003-1588-5414, CVU CONACYT ID: 162342 \\ ID $2^{\text {nd }}$ Coauthor: Laura Maryela Pérez-Castañeda / ORC ID: 0000-0002-6649-8927, CVU CONACYT ID: 173963 \\ ID $3^{\text {rd }}$ Coauthor: Jorge Sergio Téllez-Martínez / ORC ID: 0000-0003-0587-0059, CVU CONACYT ID: 40084
}

DOI: $10.35429 /$ JSI.2021.16.5.20.26

Received March 14, 2021; Accepted June 29, 2021

\begin{abstract}
Chronic kidney disease is generally complicated by poor care or by ignoring it. Among the causes that influence these conditions are obesity, diabetes, smoking, or genetic inheritance. Coordinated efforts are currently being made in multiple countries to control a strong case rate. The clinical techniques of treatment rely on the efficiency of blood purification (function that's done by kidneys in organisms). Therefore, there is great interest in the development of devices that accomplish this function. Hemofiltration through porous membranes is an efficient process, but the flow conditions in a microchannel system can be complex. Analysis of blood flow in a parameterized conduit arrangement shows streams with desired trajectories, others are held back (stagnant), and others return to the stream from which it's separated. In addition, the friction conditions and the reduction of the area drastically reduce the movement of the fluid, promoting clogging and consequently the inhibition of filtering. Based on these simulation results, it was proposed that the membrane coupling system could be modified to eliminate extensive flow in conduits generating a new concept of separation through a threshold.
\end{abstract}

Hemofiltration, Porous membrane, Flow simulation

\begin{abstract}
Resumen
Generalmente una enfermedad renal crónica se complica por atención deficiente o en algunos casos por ignorarla. Entre las causas principales que influyen en este padecimiento destacan: la obesidad, la diabetes, el tabaquismo o la herencia genética. Las técnicas clínicas de tratamiento recaen en la eficiencia de depuración de sangre (función que realizan los riñones en los organismos). Por lo tanto, existe un gran interés en el desarrollo de dispositivos que cumplan esta función. Se considera que el proceso de hemofiltración es eficiente pero las condiciones de flujo en conductos diminutos pueden ser complejas. El análisis del flujo de sangre en un arreglo de conductos parametrizado muestra que existen corrientes con trayectorias deseadas, otras son retenidas (estancamiento) y otras retornan a la corriente de donde se separó. Además, las condiciones de fricción y la reducción de área reducen drásticamente el movimiento del fluido promoviendo obstrucciones y en consecuencia la inhibición del filtrado. De acuerdo con estos resultados obtenidos por simulación, se propone que el sistema de acoplamiento de membranas puede modificarse para eliminar el flujo extenso en conductos generando un nuevo concepto de separación a través de un umbral.
\end{abstract}

Hemofiltración, Membrana porosa, Simulación de flujo

Citation: NUÑEZ-HERNÁNDEZ Lourdes Nohemi, KANTUN-UICAB María Cristina, PÉREZ-CASTAÑEDA Laura Maryela, and TÉLLEZ-MARTÍNEZ Jorge Sergio. Methodology for the design of a multilayer polymeric membrane system with potential use in hemofiltration. Journal of Systematic Innovation. 2021. 5-16: 20-26

\footnotetext{
* Correspondence to Author (e-mail: lulisnun@gmail.com)

$\dagger$ Researcher contributing as first author.
} 


\section{Introduction}

According to the reports presented at the World Congress of Nephrology (ISN, 2021), chronic kidney diseases are a global problem since 1 in 10 people in the world suffers from that. A blood and urine test are part of routine tests that look at glomerular filtration rate, which measures the kidneys' ability to filter blood. Also, the presence of protein in the urine is measured as a disease prevention parameter.

The term dialysis has been coined to define the procedure that replaces the function of a kidney. In the dialysis technique, a filtering process is developed through a porous membrane that allows the flow of small molecules of urea, water, creatinine, and glucose. Red blood cells, white blood cells, platelets, and most proteins in plasma are retained (Li Norman, Fane Anthony, Winston Ho, \& Matsuura, 2008).

The term porous membrane refers to a solid or liquid material capable of separating two macroscopic phases, whether liquid, gas, solid, having a selective control of the transfer of mass and energy between them. The transport mechanisms of chemical species through membranes can be define as convectivediffusive. Depending on the physical characteristics of the membranes, some predominates. In this sense, research is currently being carried out to design an efficient blood flow purification device (Forni \& Hilton, 1997) (Mott, et al., 2020) (Stamatialis, et al., 2008) (Mollahosseini, Abdelrasoul, \& Shoker, 2020) (Lenshof \& Laurel, 2009) (Yu, et al., 2017).

\footnotetext{
The development of biocompatible polymeric membrane manufacturing technologies has allowed researchers in the dialysis processes in any treatment modes: Hemodialysis, Hemofiltration or Hemodiafiltration to be optimized. Recent research has shown that membrane filtration analysis through simulation programs is validated with experimental measurements (R., S., S., P., \& K., 2020) (Chandra, Pathiwada, \& Chattopadhyay, 2019) (De Napoli, et al., 2014) (Eloot, 2004) (Filipovic, 2020) (Foughalia, Rosminazuin, Anis, \& Noorjannah, 2015) (Restrepo-Flórez \& Maldovan, 2018) (Tahvildari, Razavi, Tavakoli, Mashayekhi, \& Golmohammadzadeh, 2015) (Yaqoob, Ahsan, Hussain, \& Ahmad, 2020).
}

In this work, hemofiltration is of particular interest. Its nature of separation by a convective mechanism defines it as a fast procedure. A fundamental part of the hemofiltration technique are the membranes contained in the dialyzer (Göhl, Konstantin, \& Gullberg, 1982). Blood is forced through the pores that are part of the internal structure of the membrane. It has been shown that up to 15 medium and large molecules are efficiently separated compared to hemodialysis, where there is a small amount of waste removed along with the already accumulated fluid. Therefore, the technological challenge is to design a multilayer membrane system that presents high permeability and selectivity of molecules without disregarding biocompatibility.

The recirculation flows in shared cells (coupled membranes) are studied using the Navier-Stokes and Brinkman equations to describe the transport of fluids in porous media. However, in this work, a parameterized model is presented that emulates a unit of the complex system of interconnected pores within a membrane.

\section{Methodology}

Multilayer membrane systems for blood purification have now been found to be of great interest. In these systems, it does an attempt to retain molecules by their size. The blood circulates through a material that contains interconnected pores resembling tunnels, but only molecules that have a size smaller than the pore circulates. The rest have been kept back on the surface of the membrane. The process can continue sequentially with subsequent membranes with fluid flow due to a pressure difference. These systems require a pumping device or a centrifugal mechanism.

It can be assume that the tunnels are of homogeneous size in a membrane. In this case, when coupling two membranes with different tunnel sizes, an interconnection with reduction is generated. The concept of tunnel link allows to proposal parametric system. Then, it shall be deemed two tunnels with bifurcations and a return connection for the flow of blood. Through this system, laminar flow simulations were performed to understand the flow pattern and the velocity field in nano-magnitude tunnels. 
Figure 1 shows this system drawn in COMSOL Multiphysics V5.2a software (COMSOL, COMSOL, 2020). The large duct measures $10 \mathrm{~nm}$ per edge and the small duct 6 nm per edge. This geometry allowed the generation of a structured mesh.

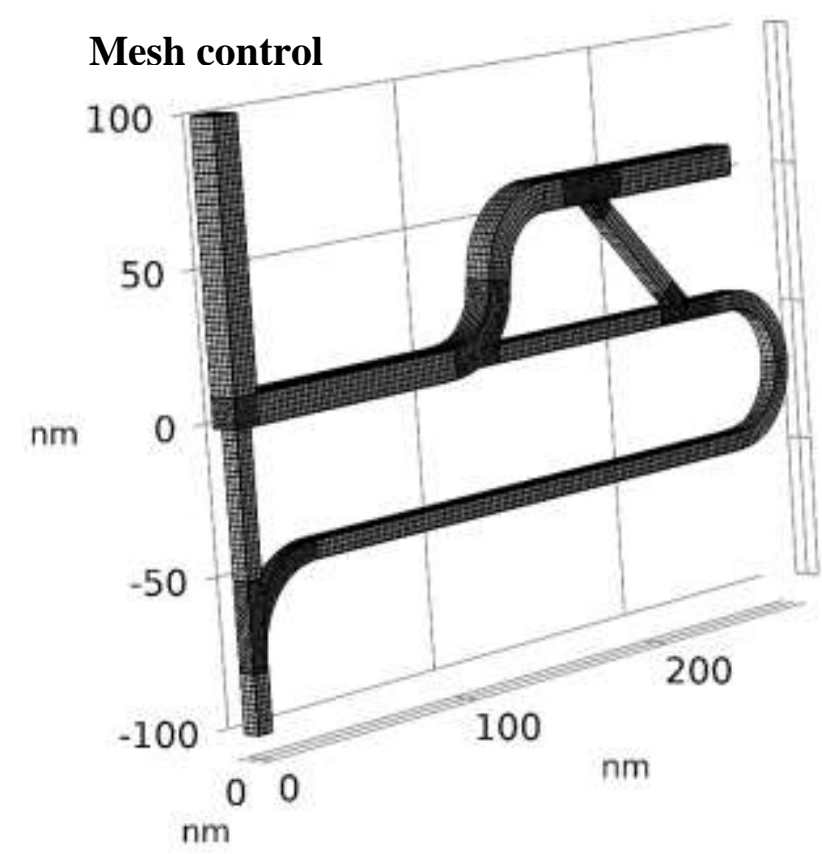

Figure 1 Parametric model of the duct link proposed for flow analysis in a membrane. COMSOL Multyphysics V5.2a.

The flow simulations were performed by solving the stationary Navier-Stokes equations and the continuity equation.

$$
\begin{aligned}
& \rho(\mathrm{u} \cdot \nabla) \mathrm{u}=\nabla[-\mathrm{pI}+\mathrm{K}]+\mathrm{F} \\
& \left.\mathrm{K}=\mu\left(\nabla \mathrm{u}+(\nabla \mathrm{u})^{\mathrm{T}}\right)\right) \\
& \rho \nabla \cdot \mathrm{u}=0
\end{aligned}
$$

Gravitational effects or external pressure conditions do not influence the studied system such that equation (1) is simplified. Simulations started with a flow magnitude as a boundary condition reported in the investigation by (Mott, et al., 2020), which implied a high speed.

The results indicated necessary changes to the system that will help improve fluid separation. The calculation of the velocity profiles makes it possible to determine the characteristics of the rapid flow of the fluid in the ducts. A region where low speed is specified determines slow mobility and the tendency to stagnation, which happens on the duct walls. Another stagnant situation occurs when a portion of the fluid remains moving in a circuit (vortex).
An analysis of the velocity field can be obtained for the parametric model and subsequently include the presence of particles. It is possible to implement the presence of particles in the streams to evaluate the interaction: 1) fluid-particle, 2) particle-particle, and 3) particle-wall. With the results, it will expect to define design parameters to obtain the proposed objective.

In COMSOL software (COMSOL, COMSOL, 2020), the equation that governs the calculation of particle trajectories from a velocity field is define as:

$\frac{d\left(m_{p} \mathbf{u}\right)}{d t}=\mathbf{F}_{t}$

Again, the system was simplified by analyze the behavior in a single bifurcation. With this change, the entrance speeds were specified between 0.2 to $20 \mathrm{~ms}^{-1}$. The analysis of the flow separation in a bifurcation as a function of the entering velocity was conclusive. These showed the separation system design needs, and with them, a new proposal for a membrane system for the convective separation of molecules of blood is in the making.

\section{Results}

Studies carried out a flow of $20 \mathrm{~ms}^{-1}$ was considered entering the large duct, while in the locks, the flows are free. The results of the velocity field are show in Figure 2.

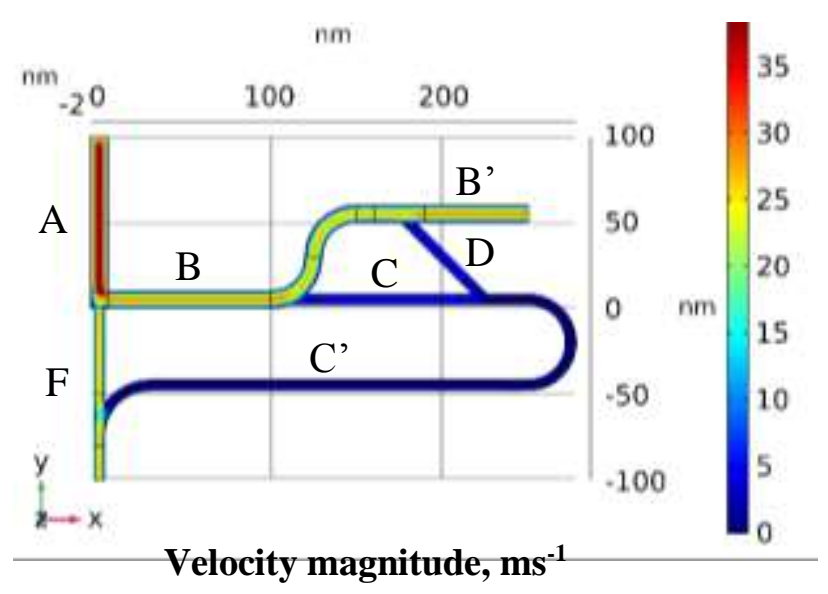

Figure 2 Velocity profile estimated in the parameterized system. COMSOL Multyphysics V5.2a. 
According to the color scale, it can observed that there is a fluid stagnation condition in the return duct because higher speed currents contribute to this stagnation. An analysis of the streamlines at branch $\mathrm{C}$ shows separate fluid returns at branch B' (See figure 3) through at branch $\mathrm{D}$ due to resistance imposed by stagnation fluid in $\mathrm{C}^{\prime}$.

In the calculations, $73.46 \%$ of the flow flows in the $\mathrm{B}$ stream. Therefore, the complementary percentage $(26.54 \%)$ is associated with the E current. The 7.05\% fraction of the flow in B flows through C. $99.3 \%$ of the flow in $\mathrm{C}$ returns to $\mathrm{B}$ 'through $\mathrm{D}$, and only $0.7 \%$ circulates through branch $\mathrm{C}^{\prime}$. Concerning the initial flow, $5 \%$ of the fluid returns through stream $\mathrm{D}$. This amount should be added to the branch E through C', and even stream D should increase it. Therefore, branch D should not exist.

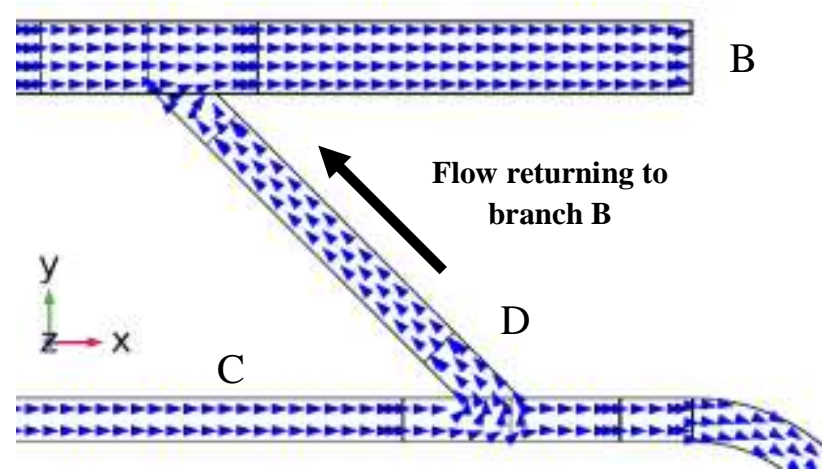

Figure 3 Normalized streamlines in arms B, C and D of the parametric system. COMSOL Multyphysics V5.2a

The elimination of branch $\mathrm{D}$ shows an improvement in separation flow in the return duct (branch C). However, the velocity continues to decrease dramatically, as shown by the particle trajectory profile on a cut plane in Figure 4. The accumulation of particles in the return duct indicates stagnation. The diameter of the particles for this analysis was $1.8 \mathrm{~nm}$.

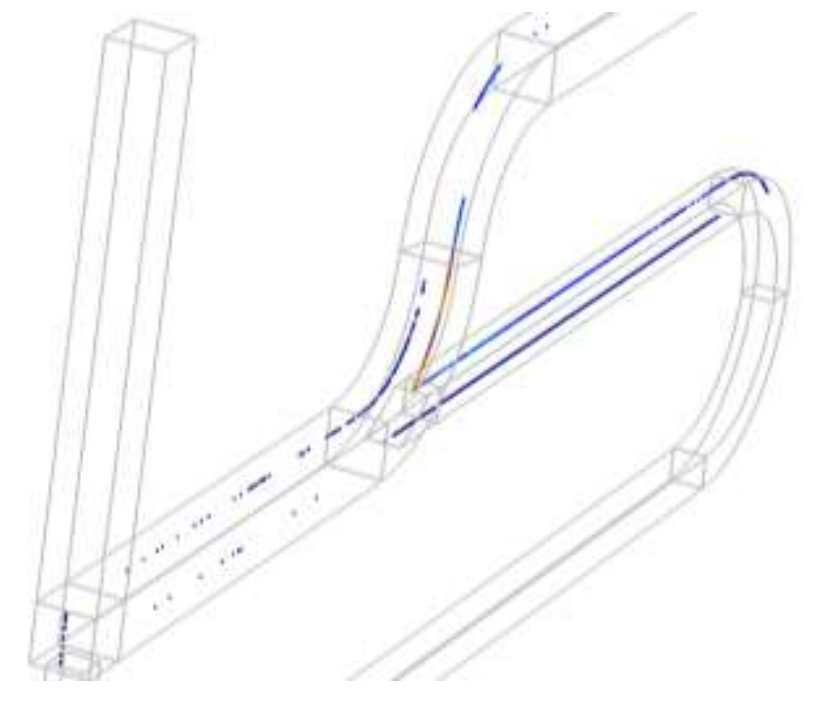

Figure 4 Particle flow in the fluid stream coinciding with the center shear plane. COMSOL Multiphysics V5.2a.

The results of this simplified model of linked pipelines indicate that there is a high possibility of unwanted returns and stagnation. In a membrane porous system, this process can multiply, and then the number of derivations, the transversal, and the length size of the conduits, should be kept to a minimum.

The bifurcation containing branches A, $\mathrm{B}$, and $\mathrm{E}$ (see figure 2) is an example of the simplicity of separation without alternate connections. A similar model was created to evaluate the rate separation of the flow in branch A towards branches $\mathrm{C}$ and $\mathrm{E}$. In this new system, the velocity field was calculated considering an input velocity of $0.2 \mathrm{~ms}^{-1}$. The flow calculations determine approximately a relationship of $89 \%$ and $11 \%$ flow in the larger and the smaller ducts. Figures 5(a) and 5(b) show the velocity field in 2D and 3D perspectives. In the contour graph, it can be observed that the current with the highest relative velocity, is found in the center of the ducts and that it reaches twice the input value.

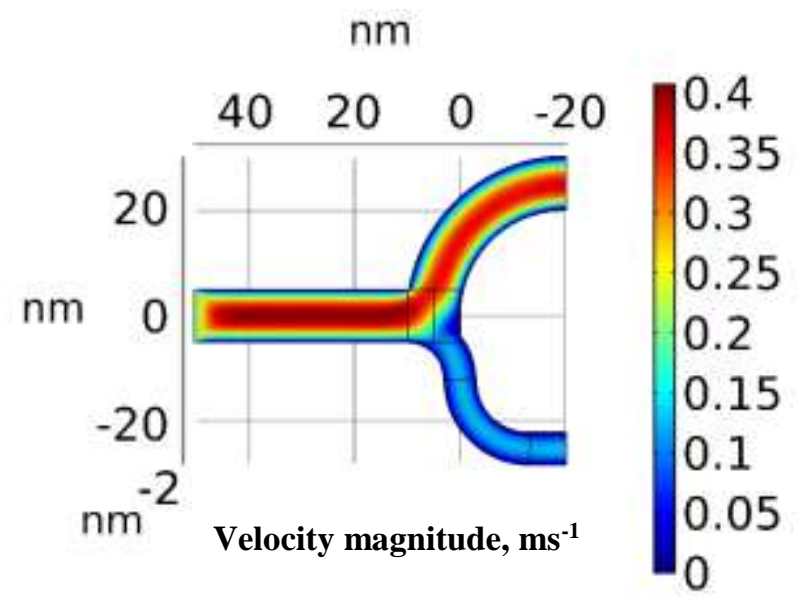

(a) 


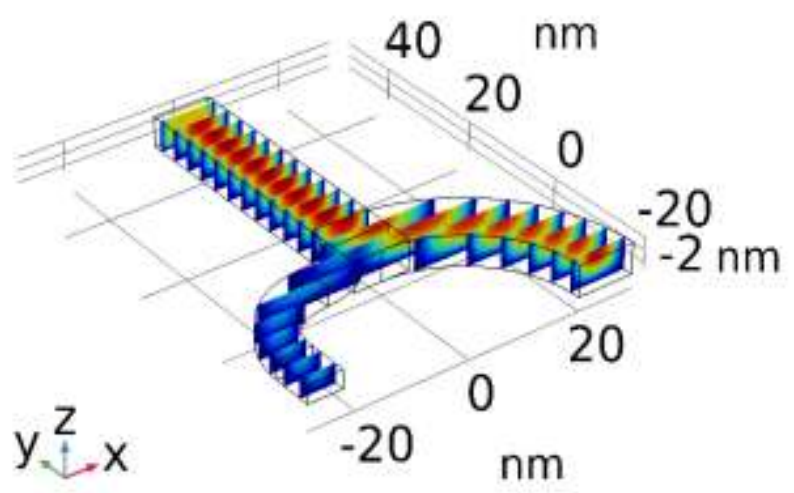

(b)

Figure 5 Velocity field in 2D and 3D perspectives at a bifurcation. COMSOL Multiphysics V5.2a

The figures show one of the sections of the system cut by symmetry. A smaller flow flows through the smaller duct due to the reduction in area and intrinsic viscous forces. The inertial forces can increase in the narrow duct region increasing the input velocity. Therefore, the velocity profiles were calculated at various input velocities between 0.2 and 20 $\mathrm{ms}^{-1}$. The results show the same pattern obtained before. Figures $6(\mathrm{a})$ and $6(\mathrm{~b})$ show the rate flow and $\%$ separation in the branches as a velocity function.

It can be observed that the percentage of separation is constant, and the flow in each branch is proportional to this. By analyzing the system, the bloodstream in the larger duct can be separated by implementing a new bifurcation. Several branches can be couple to obtain a consecutive separation. The process is attractive since it develops at higher rate than a diffusive process and doesn't require great external forces. However, it's not already as efficient for processing high volumes of blood. The problem of circulation through ducts where friction can lead to stagnation tendencies continues.

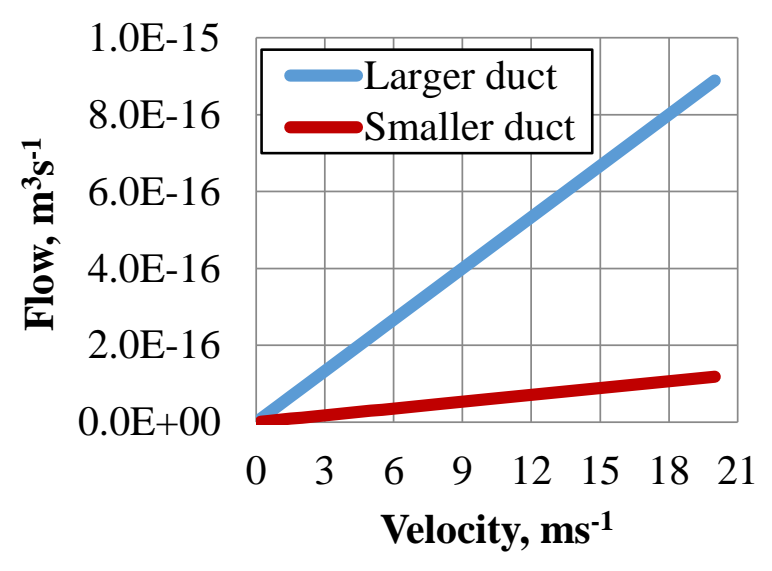

(a)

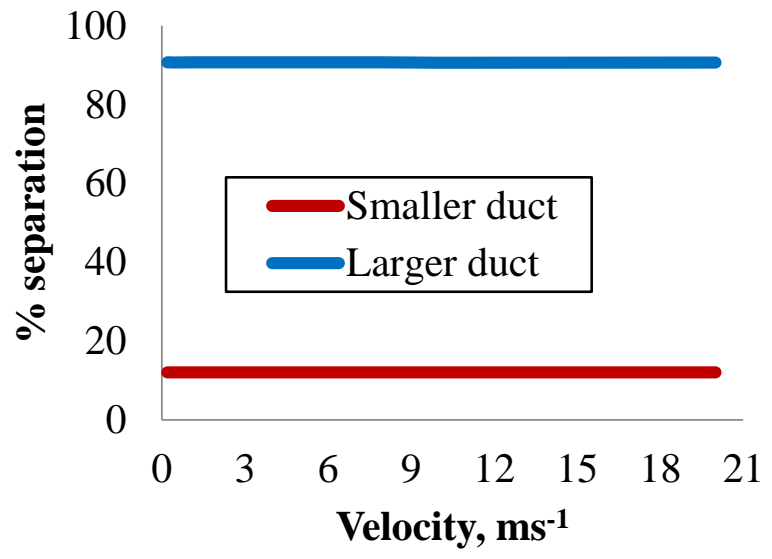

(b)

Figure 6 Relation between rate flow and separation $\%$ in the branches as a velocity function. MS Excel 2013

An alternative to the separation of molecules from the bloodstream is to channel them free up to a threshold where only molecules of selected size can cross. In this case, the molecules would be propelled from one room towards the transfer threshold to another room. The "threshold" can be describe as a "door" between two spacious rooms. This new system avoids most of the friction by contact between the blood and the wall ducts.

In this sense, a concentric container system will assume whose walls are separated by a distance that generates a collection volume. A centrifugation system to drive fluid from a central container will also be consider. Walls are compounds by two assemble membranes ablation grooved such that they set the threshold. The result of the blood flow pattern analysis of this concept is shown in Figure 7.

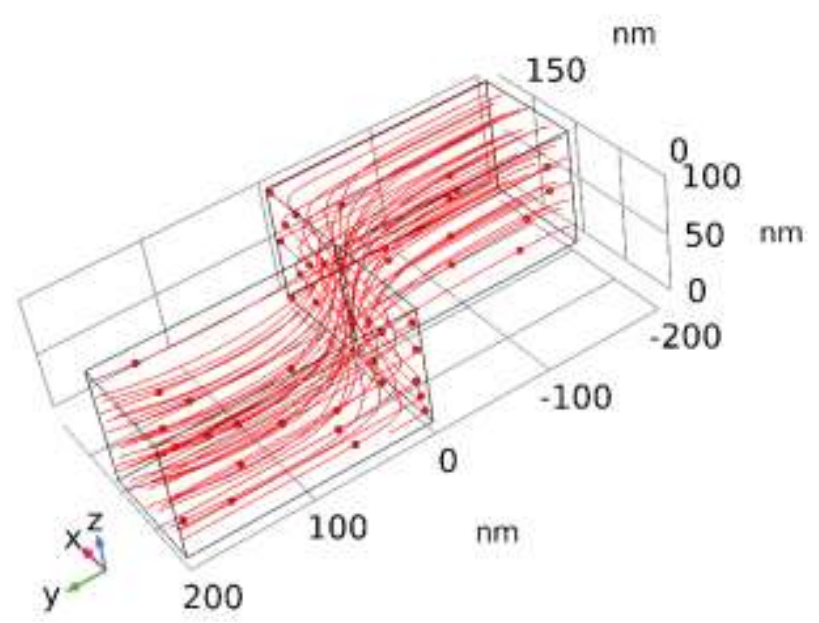

Figure 7 Streamline of blood flow through the membrane coupling system defining the separation by means of a threshold. COMSOL Multiphysics V5.2a 
The particular future work of hemofiltration in this investigation will be based on this approach derived from duct flow. The concept of flow through the threshold and turbulent flow patterns have been obtained in a system centrifuged at $500 \mathrm{rpm}$ that generates velocities of $20 \mathrm{~ms}^{-1}$ on the inner wall of a cylindrical container. Figure 8 shows the velocity field calculated using the $\mathrm{k}-\epsilon$ turbulence model. The color scale determines the speed profile reached in the system.

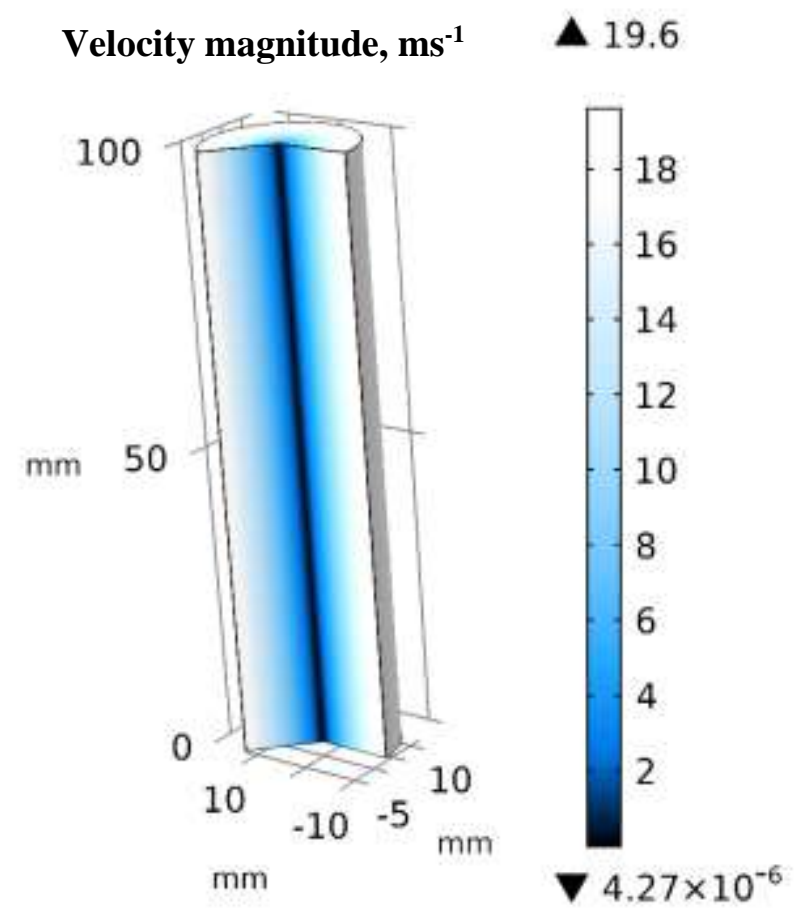

Figure 8 Velocity field of a blood fluid subjected to centrifugation. COMSOL Multiphysics V5.2a

The system was defined with a $4: 1$ ratio, height:diameter, to avoid the edge effect. From now on, the particle trajectory calculation will be implemented. The approach behavior of the blood molecules to the threshold and the crossing capacity will be analyze.

\section{Thanks}

Thanks to the postgraduate program of the Universidad Politécnica Juventino Rosas for providing the development and dissemination of this article.

Thanks are given to the Posgrado en Ciencias en Metalurgia at the Tecnológico Nacional de México campus Morelia for facilitating the use of the COMSOL Multiphysics software.

\section{Conclusions}

In this work, it's mathematically supported by simulation that the hydrodynamic separation technique can be obtained by controlling the speed of flow, the geometry of the tiny channels, and the configuration of the outlets in porous membranes. The process is attractive since it develops at a high velocity compared to a diffusive process.

The simplification of a complex system of tunnels in a porous membrane led to creating conditions for the derivation of the flow of a pipeline in two branches to obtain sequential filtering of particles of different sizes taking advantage of convection in tiny channels. As a result of the analysis, it was demonstrated that the flow capacity at nanometric scales would be adapt to smaller fluid volume processing systems.

In a dialysis process, a significant amount of blood is required to be processed for cleaning. In this sense, although the filtering process imitating a natural procedure can be developed, it doesn't apply to the necessary flow levels.

Essentially, it was shown that the change of flow to narrow passages is not a desirable condition. Therefore the path in the separation is believed to be reduced to the crossing of an interface (cross a threshold). According to the analysis, this kind of separation can be adapt to the most common blood cell separation technique, centrifugation, with the component of obtaining a high manipulation of the protein separation.

\section{References}

Chandra, A., Pathiwada, D., \& Chattopadhyay, S. (2019). COMSOL simulation and experimental validation of promoter geometries facilitating citric acid transport in electrodialysis. Chemical Engineering Research and Design, 142-386.

COMSOL, I. (2020). COMSOL. Retrieved from www.comsol.com/

COMSOL, I. (2020). COMSOL Video Gallery. Retrieved from www.comsol.com/video/modeling-biosensortransport-and-reactions-in-comsol-multiphysics 
De Napoli, I., Zanetti, E. M., Fragomeni, G., Giuzio, E., Audenino, A. L., \& Catapano, G. (2014). Transport modeling of convectionenhanced hollow fiber membrane bioreactors for therapeutic applications. Journal of Membrane Science,(471), 347-361. https://doi.org/10.1016/j.memsci.2014.08.026.

Eloot, S. (2004). Experimental and Numerical Modeling of Dialysis. Ghent, Belgium: Ghent University .

Filipovic, N. N. (2020). Simulation of organ-ona-chip systems. Biomaterials for Organ and Tissue Regeneration, https://doi.org/10.1016/b978-0-08-1029060.00028-3.

Forni, L. G., \& Hilton, P. J. (1997). Continuos Hemofiltration in the Treatment of a Cute Renal Failure. The New England Journal of Medicine, 1303-1309.

Foughalia, A., Rosminazuin, A., Anis, N., \& Noorjannah, I. (2015). Simulation of an hybrid blood cells micro-separator. IEEE, 1-4. 10.1109/RSM.2015.7354955.

Göhl, H., Konstantin, P., \& Gullberg, C. A. (1982). Hemofiltration membranes. Contributions to Nephrology. Hemofiltration (págs. 20-30). Berlín: Karger.

ISN, I. S. (2021). Advancing Kidney Health Worldwide. Obtenido de https://www.theisn.org/wcn/

Lenshof, A., \& Laurel, T. (2009). Continuous separation of cells and particles in microfluidic systems. Chemical Society Reviews(39), 12031217. DOI: 10.1039/b915999c.

Li Norman, N., Fane Anthony, G., Winston Ho, W. S., \& Matsuura, T. (2008). Advanced Membrane Technology and Applications. New Jersey, U.S.A.: John Wiley \& Sons, Inc.

Mollahosseini, A., Abdelrasoul, A., \& Shoker, A. (2020). A Critical Review of Recent Advances in Hemodialysis Membranes Hemocompatibility and Guidelines for Future Development. Materials Chemistry and Physics, En revisión.
Mott, V. L., Finley, V., Truslow, J., Rossetti, D., Santos, J., Gusman, J., Charest, J. (2020). Multipoint Dilution Hemofiltration: A New Technology for Maximum Convective Clearance. Thoughts \& Progress, 753-763.

R., B., S., K., S., U., P., C. S., \& K., S. (2020). CFD modeling of vacuum membrane distillation for removal of Naphthol blue black dye from aqueous solution using COMSOL Multiphysics. Chemical Engineering Research and Design(158), 77-88. https://doi.org/10.1016/j.cherd.2020.03.016.

Restrepo-Flórez, J. M., \& Maldovan, M. (2018). Breaking separation limits in membrane technology. Journal of Membrane Science, August(566), 301-306. https://doi.org/10.1016/j.memsci.2018.08.056.

Stamatialis, D. F., Papenburg, B. J., Giron, M., Bettahalli, S., Schmitmeier, S., \& Wesslingm, M. (2008). Medical Application of Membranes: Drug Delivery. Artificial Organs and Tissue Engineering. Journal of Membrane Science, 134.

Tahvildari, K., Razavi, S. M., Tavakoli, H., Mashayekhi, A., \& Golmohammadzadeh, R. (2015). Modeling and Simulation of Membrane Separation Process Using Computational Fluid Dynamics. Arabian Journal of Chemistry, 7278.

Yaqoob, T., Ahsan, M., Hussain, A., \& Ahmad, I. (2020). Computational Fluid Dynamics (CFD) Modeling and Simulation of Flow Regulatory Mechanism in Artificial Kidney Using Finite Element Method. Membranes - Open Access Journal, 1-18.

Yu, X., Shen, L., Zhu, Y., Li, X., Yang, Y., Wang, X., . . . Hsiao, B. S. (2017). High performance thin-film nanofibrous composite hemodialysis membranes with efficient middlemolecule uremic toxin removal. Journal of Membrane Science, September(523), 173-184. https://doi.org/10.1016/j.memsci.2016.09.057. 